\title{
Does equity in healthcare spending exist among Indian states? Explaining regional variations from national sample survey data
}

Rinshu Dwivedi ${ }^{1}$ and Jalandhar Pradhan ${ }^{2^{*}}$

\begin{abstract}
Background: Equity and justice in healthcare payment form an integral part of health policy and planning. In the majority of low and middle-income countries (LMICS), healthcare inequalities are further aggravated by Out of Pocket Expenditure (OOPE). This paper examines the pattern of health equity and regional disparities in healthcare spending among Indian states by applying Andersen's behavioural model of healthcare utilization.

Methods: The present study uses data from the $66^{\text {th }}$ quinquennial round of Consumer Expenditure Survey, of the National Sample Survey Organization (NSSO), conducted in 2009-10 by Ministry of Statistics and Programme Implementation (MoSPI), Government of India (Gol). To measure equity and regional disparities in healthcare expenditure, states have been categorized under three heads on the basis of monthly OOPE i.e., Category A (OOPE > =INR 100); Category B (OOPE between INR 50 to 99) and Category C (OOPE < INR 50). Multiple Generalised Linear Regression Model (GLRM) has been employed to explore the effect of various socio-economic covariates on the level of OOPE.

Results: The gap in the ratio of average healthcare spending between the poorest and richest households was maximum in Category A states (richest/poorest $=14.60$ ), followed by Category B (richest/poorest 11.70) and Category $C$ (richest/poorest 11.40). Results also indicate geographical concentration of lower level healthcare spending among Indian states (e.g., Odisha, Chhattisgarh and all the north-eastern states). Results from the multivariate analysis suggest that people residing in urban areas, having higher economic status, belonging to non-Muslim communities, non-Scheduled Tribes (STs), and non-poor households spend more on healthcare than their counterparts.

Conclusions: In spite of various efforts by the government to reduce the burden of healthcare spending, widespread inequalities in healthcare expenditure are prevalent. Households with high healthcare needs (SCs/STs, and the poor) are in a more disadvantaged position in terms of spending on health care. It has also been observed that spending on healthcare was comparatively lower among backward or isolated states. No doubt, the overall social security measures should be enhanced, but at the same time, looking at the regional differences, more priority should be assigned to the disadvantaged states to reduce the burden of OOPE. It is proposed that there is need to increase government spending, especially for the disadvantaged states and population, to minimise the burden of OOPE.
\end{abstract}

Keywords: Equity, Inequalities, Healthcare utilisation, GLRM, OOPE

\footnotetext{
*Correspondence: jpp_pradhan@yahoo.co.uk

${ }^{2}$ Department of Humanities and Social Sciences, National Institute of

Technology, Rourkela, Odisha 769 008, India

Full list of author information is available at the end of the article
} 


\section{Background}

Health equity has been an important policy issue since the Alma-Ata Declaration of the World Health Organization (WHO). Since then all countries have been making efforts to reduce health inequities. Concerns have been expressed regarding the quality and availability of healthcare services in low and middle-income countries (LMICs) [1, 2]. Accessibility and affordability of healthcare services are among the major healthcare challenges faced by developing countries [3-5]. Financial barriers are key limitations to access healthcare services in LMICs since Out-of-Pocket Expenditure $(\mathrm{OOPE})^{1}$ constitutes a significant proportion of healthcare expenditure [6-8]. Globally, about 1.3 billion people are deprived of access to effective and affordable health care. Majority of households spend more than $40 \%$ of their household income on medical treatment $[9,10]$.

Possibilities are high of many households residing in LMICs being pushed into poverty when faced with high medical expenses, especially when it is combined with loss of income due to adverse health outcomes [11, 12]. Measures to promote financial protection through universal health coverage (UHC) strategize to ensure that people would have access to health services without risking financial impoverishment [13-15]. Health systems in many LMICs are financed through key sources such as, taxation, social security schemes, private health insurance and OOPE [15].

More than half of the world's population does not have access to formal social protection schemes $[16,17]$. Majority of the households who are unable to pay for using healthcare services either do not seek care or resort to short-term coping strategies such as minimizing food expenses, using past savings, and removing children from school to manage the financial shortfall [18-20]. Short-term coping strategies may result in higher cost in the long run, leading to impoverishment and poverty. These households are not captured in poverty estimates, as high healthcare cost raises their expense above the threshold level and they are considered non-poor [14].

Literature shows that the level of health payments also differs significantly with variations in certain specific characteristics of the households. Poor and disadvantaged sections of the population face more financial risks and need better financial mechanisms to avail healthcare services [21, 22]. Literature also indicates differentials in healthcare spending among various regions as well as segments of population [23, 24].

\section{Indian scenario}

Equity and justice in healthcare payment are integral parts of health policy draft in India [25, 26]. Healthcare system in India is highly privatized and the main source of financing is OOPE $[27,28]$. OOPE does not provide any financial protection; as a result, such households incur heavy expenses in availing healthcare services [29]. Expenditure on healthcare pushes a large number of families into poverty in India as they do not have sufficient spending power due to low level of income or sometimes, no fixed source of income [30-32].

In India, more than $90 \%$ of the workforce, especially people who belong to socially and economically underprivileged sections of society, is engaged in informal economic activities. ${ }^{2}$ As insurance facilities are available only to the workforce in the formal sector, majority of such households are not covered under any social protection scheme $[33,34]$. In the case of ill health, these households have to spend from their own pockets. Inadequate provisioning of health care facilities, coupled with a highly privatized health sector, further worsens the financial status of the poor and marginalized groups of the population $[35,36]$. It leads them into financial catastrophe and further deepens existing poverty [36-39].

Level and pattern of OOPE are determined on the basis of socio-economic affiliations in India. Differences also prevail in the health spending and level of socio-economic inequalities among different Indian states. Different variables such as, socio-economic status, class, religious affiliation, place of residence, gender and age are used to classify the population [35, 40, 41]. Among all these factors, economic status and caste affiliation are considered most important classificatory variables for analyzing socio-economic inequalities in health and health care expenditure in India [42-45]. Socio-economic inequalities are highly unfavourable for healthcare, especially when society is more diversified, multi-ethnic, overpopulated and undergoing significant but unequal economic growth [46].

There is evidence of wider inter-state differentials in public spending and health infrastructure across Indian states. The level of public spending on health in few of the backward states such as, Bihar, Jharkhand, and Odisha, is very low in comparison to Kerala, Punjab and other developed states [47]. Studies also indicate increasing interstate inequalities in health spending in recent years. The difference between per capita OOPE among developed states such as, Kerala and Punjab, and backward states such as, Jharkhand, Chhattisgarh and Orissa, has increased, leading to greater divergence between these states [48, 49].

Only a limited number of studies are available in the Indian contexts which have tried to examine the level of equity and regional variations in healthcare spending, by categorizing Indian states. We have classified the states on the basis of OOPE into three categories i.e., high, medium and low level of OOPE, and examined the pattern of inequalities in health spending among these states. This paper makes an effort to examine the pattern of health equity and regional disparities in healthcare spending among the Indian states by applying Andersen's behavioural model of healthcare utilization. 


\section{Data and methods \\ Data}

Data is used from the $66^{\text {th }}$ quinquennial round of the Consumer Expenditure Survey (CES), National Sample Survey Organisation (NSSO), conducted by the Government of India (GoI) in 2009-10. The present study uses schedule type-1 questionnaire, which covers 100,855 households, of which nearly 59\% are located in rural areas. We have taken into consideration consumption expenditure as a measure of healthcare spending. As there are noticeable differences between developed and developing countries regarding the nature and extent of formal employment, level of poverty and health indicators, consumption is used as the standard measure of overall material well-being among developing countries. In developing countries, only a limited segment of the population is employed in the formal sector while a majority of the population is engaged in the informal sector without any fixed source of income. Under such circumstances, consumption is better measured than income for poor families, and is less vulnerable to under-reporting bias. There are also conceptual and economic reasons to prefer consumption measure rather than income because consumption is a more direct measure of material well-being. Spending on healthcare not only depends on income but also on sources such as, savings, borrowings and other sources. Available literature tends to support the consumption method, signifying that consumption should be used to assess spending on healthcare and to set other benefit criteria $[6,8,40,50]$.

The CES rounds contain information on household consumption expenditure for both food and non-food items. Healthcare expenses are covered under non-food section and can be broadly classified into institutional and non-institutional health expenditure. The recall period is 365 days for institutional expenses and 30 days for noninstitutional expenses. This study uses data on OOPE for both institutional (inpatient) ${ }^{3}$ and non-institutional (outpatient $)^{4}$ expenditure by using a 30-day recall period. Institutional expenditure was available for a 365-day recall period; so, for the purpose of the study, it has been converted into 30-day recall period (see Appendix). The approach to measure OOPE for healthcare payments has been adopted from Wagstaff and Doorslaer [40]. In addition to medical expenditure, information is also available on socio-economic and demographic characteristics of the households. The questionnaire contains information about individuals and households such as, place of residence (urban/rural), religious affiliation (Hinduism, Islam, Christianity, Sikhism, Jainism, Buddhism, Zoroastrianism and others), social group ${ }^{5}$ (Scheduled Caste $(\mathrm{SC})^{6}$, Scheduled Tribe (ST), ${ }^{7}$ Other Backward Caste $(\mathrm{OBC})^{8}$ and Others).

\section{Methods}

States has been classified into three categories i.e., Category A (Higher OOPE), Category B (Middle-level OOPE) and Category $\mathrm{C}$ (lower OOPE) states. Though it is ideal to categorize the states on the basis of mean/median values of OOPE, our objective was to look into the equity and efficiency aspects among the states with higher, lower and middle levels of OOPE. First, we categorized the states on the basis of the level of monthly OOPE in three categories i.e., Category A (OOPE > =INR 100); Category B (OOPE between INR 50 to 99) and Category C (OOPE < INR 50). Next, mean OOPE was calculated for the three categories of states (A, B, and C), by selected socio-economic covariates. Lastly, we employed multiple Generalized Linear Regression Model (GLRM) to explore the effect of various socio-economic covariates on the level of OOPE. Our outcome variable OOPE was usually non-parametric and positively skewed with influential outliers. Traditional Ordinary Least Square (OLS) regressions with log-transformation cannot accurately capture the skewness in the data. It can provide inferences in the natural units of average healthcare expenditure. [51]. GLRM can flexibly handle the skewed datasets and reduce the problem of outcome transformation $[52,53]$. We have employed GLRM with gamma distribution and log link function to examine the various determinants of OOPE [54].

\section{Dependent variable}

The dependent variable for the study is OOPE among all Indian states and UTs (both rural and urban).

\section{Independent variable}

The independent variables are: residence (Rural /Urban), economic status (wealth quintile), religious group (Muslims and others), and social group (Scheduled Tribe and others). For measurement of the economic status, we have used the households quintile based ranking on MPCE, separately for both urban and rural areas. In the Indian social setup, caste is broadly divided into different groups such as, SCs, STs, $\mathrm{OBCs}$ and others category. We have re-classified the caste groups into two i.e., STs and Others (Including SCs, OBCs and others), and religious categories, into Muslims and non-Muslims, (Non-Muslims include Hindus, Christians, Sikhs, Buddhism, Jainism, Zoroastrianism and other smaller religious communities).

\section{Conceptual framework}

This paper also tries to apply Andersen's behavioural model of healthcare utilization which was initially developed in the late1960s $[55,56]$. As per this model, use of healthcare services by the households is a function of their predisposition to use services, factors which allow them to use these services and their need to use these services. This model categorizes the use of health care 
services as a function of three elements - predisposing, enabling and need factors. Predisposing factors include demographic variables such as, residence and socioeconomic status (social and religious group). Enabling factors include the wealth or economic status of the population; level and pattern of OOPE, which is an indicator of health status, are considered need factors.

Based on Andersen's model, we have also classified the factors determining the use of healthcare services in three categories: predisposing, enabling and need factors (Fig. 1). We have included place of residence, religious and social affiliation as predisposing factors; economic status has been considered an enabling factor while the level of health spending has been taken into consideration as a need factor.

\section{Results}

\section{Inter-state differentials in OOPE}

Out of 100,855 households, 16,887 (16.74\%) are in Category $A$ states, 57,829 (57.34\%) are in Category B and 26,139 (25.92\%) are in Category C. States have been categorized into three groups on the basis of average monthly OOPE i.e., low, medium and high OOPE (Table 1).

Figure 2 shows that average monthly per capita healthcare expenditure was the highest in states such as, Punjab, Chandigarh, Maharashtra, Goa, Kerala and Pondicherry (Category A). Category $B$ states are more concentrated towards southern India such as, Karnataka, Andhra Pradesh, Tamil Nadu, Andaman and Nicobar, Lakshadweep as well as northern states such as, Jammu and Kashmir (J\&K), Delhi, Uttarakhand, Haryana, Himachal Pradesh, Rajasthan and Uttar Pradesh; states such as, Madhya Pradesh, Gujarat, Tripura and West Bengal are exceptions. Category $C$ states are located in the north-eastern, central and southern eastern regions such as, Dadra Nagar Haveli, Daman \& Diu, Sikkim, Nagaland, Assam, Manipur, Meghalaya, Mizoram, Arunachal Pradesh, Bihar, Jharkhand, Chhattisgarh and Orissa.

Majority of the north-eastern states fall in Category $C$ and their average monthly expenditure on healthcare is less than INR 50. Results also indicate geographical concentration of lower level of health spending among these states (e.g., Odisha, Chhattisgarh and all the northeastern states). The gap in terms of average monthly healthcare spending between the richest and the poorest households was the highest in Category $A$ (Richest/Poorest $=14.60)$ states, followed by Category $B$ (Richest/Poorest $=11.70$ ) and Category $C$ (Richest/ Poorest $=11.40)$ (Table 2). Similarly, in Category $C$ states, there was marginally higher gap among Muslims and Non-Muslims (Non-Muslims/Muslims =1.53) households in terms of healthcare spending followed by Category $A$ (Non-Muslims/Muslims =1.13) and Category $B$ (Non-Muslims/Muslims =1.13). As far as social group affiliation is concerned, the inequalities in terms of OOPE was nearly the same in both Category $A$ (Others $/ \mathrm{ST}=2.58)$ and $B($ Others $/ \mathrm{ST}=2.34)$ states, and comparatively lower in Category $C$ states (Others/ST = 1.17). The gap between urban and rural households in terms of healthcare spending was marginally higher in the Category $C$ states (Urban/Rural $=1.92$ ), followed by Category $B($ Urban/Rural $=1.62)$ and Category $A$ states (Urban/Rural =1.26). Overall, in the Indian context, inequalities in terms of average monthly healthcare spending were observed between the richest and the poorest (Richest $/$ Poorest $=13.19)$, STs and Others (Others $/ \mathrm{ST}=$ 2.50), rural and urban (Urban/Rural $=1.49$ ) households, and between Muslims and Non-Muslims (Non-Muslims/ Muslims =1.11).

\section{Results from multivariate analysis}

The result of the multivariate analysis is presented in Table 3. In Category $A$ states, the level of OOPE is significantly lower for households that belong to the lowest wealth quintile $(\beta=-1.501, \rho=0.001)$, as compared to their counterparts in Category B and C states. The impact of economic status on the level of OOPE was similar in the other two categories of states i.e., Category $B(\beta=-1.419, \rho=0.000)$ and $C(\beta$ $=-1.139, \rho=0.000$ ) states. Similarly, as far as social group affiliation is concerned, the level of OOPE was the lowest among ST population as compared to their counterparts in all the categories of the states i.e., Category $A(\beta=-2.97, \rho=0.001), B \quad(\beta=-0.386, \rho=$ $0.000)$, and $C(\beta=-1.281, \rho=0.000)$. Category $C$ states

Table 1 Categorization of all Indian states by mean OOPE (NSSO, CES-2009-10)

\begin{tabular}{|c|c|c|c|}
\hline Category & Mean OOPE (INR) & States & $\begin{array}{l}\text { Number of } \\
\text { households (\%) }\end{array}$ \\
\hline A & 100 or more & Punjab, Chandigarh,Maharashtra, Goa, Kerala, Pondicherry & $16,887(16.74)$ \\
\hline B & 50 to 99 & $\begin{array}{l}\text { Karnataka, Delhi, Madhya Pradesh, Rajasthan, J\&K, Andaman and Nicobar, Uttar Pradesh, Tripura, } \\
\text { West Bengal, Andhra Pradesh, Gujarat, Uttarakhand, Lakshadweep, Haryana, Tamil Nadu, Himachal } \\
\text { Pradesh }\end{array}$ & $57,829(57.34)$ \\
\hline C & Below 50 & $\begin{array}{l}\text { Dadra Nagar Haveli, Sikkim, Nagaland, Assam, Manipur, Daman \&Diu, Meghalaya, Mizoram, Bihar, } \\
\text { Jharkhand, Chhattisgarh, Orissa, Arunachal Pradesh }\end{array}$ & $26,139(25.92)$ \\
\hline
\end{tabular}

Source: Compiled from NSS CES Report (2009-10); computed by author using the unit level data records of CES 2009-10 


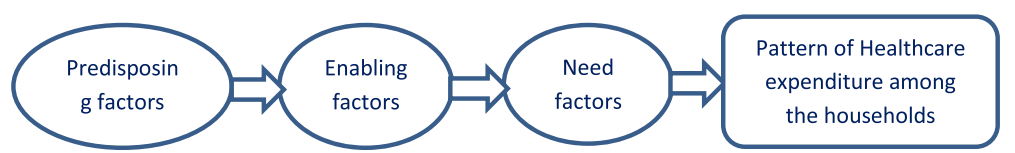

Fig. 1 Study framework adapted from Anderson's Model. Source: Partially adapted from Andersen's behavioural model [55]

recorded lower level of spending among Muslims $(\beta$ $=-0.220, \rho=0.000)$, and rural communities $(\beta=-0.158$, $\rho=0.000)$. Place of residence and religious affiliation are important predictors of healthcare spending among the Category $C$ states. However, these factors do not play any significant role in determining the level of OOPE among Category $A$ and $B$ states.

As per the Andersen's model, in the Indian context, predisposing factors such as, residence, religion and social group affiliation have a significant impact on the pattern of healthcare spending among households. Households in rural areas $(\beta=-0.102, \rho=0.00)$, belonging to the Muslims community $(\beta=-0.101, \rho=$ $0.00)$, and ST social group $(\beta=-0.634, \rho=0.00)$ have recorded significantly lower level of OOPE than their counterparts. Enabling factors indicate that spending on healthcare among population belonging to the lowest economic status was significantly lower $(\beta$ $=-1.273, \rho=0.00)$ as compared to other economic categories.

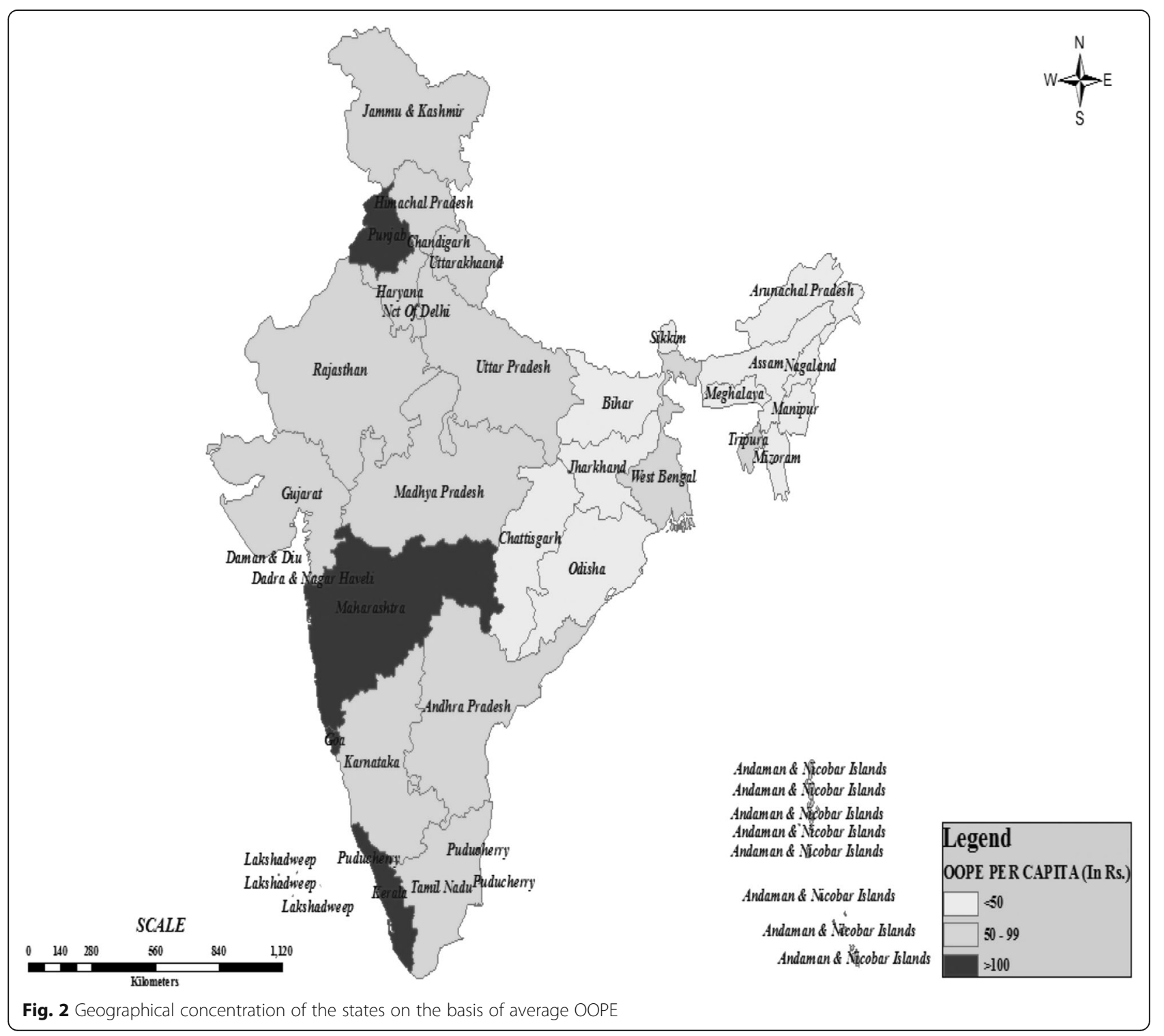


Table 2 Interstate differentials in mean OOPE by residence, economic status, religion and social group

\begin{tabular}{|c|c|c|c|c|}
\hline \multirow[b]{2}{*}{ Covariates } & \multicolumn{3}{|c|}{ Categories of states } & \multirow[b]{2}{*}{ All India } \\
\hline & Category A & Category B & Category C & \\
\hline \multicolumn{5}{|l|}{ Residence } \\
\hline Rural & 112.82 & 56.93 & 27.01 & 57.02 \\
\hline Urban & 142.71 & 92.35 & 51.9 & 84.86 \\
\hline (Ratio Urban/Rural) & 1.26 & 1.62 & 1.92 & 1.49 \\
\hline \multicolumn{5}{|l|}{ Economic status } \\
\hline Poorest & 19.60 & 19.75 & 16.28 & 18.68 \\
\hline Second poorest & 47.92 & 46.25 & 28.51 & 43.22 \\
\hline Middle & 72.15 & 71.92 & 42.20 & 67.96 \\
\hline Second Richest & 123.27 & 94.98 & 62.88 & 97.26 \\
\hline Richest & 286.23 & 230.94 & 185.60 & 246.27 \\
\hline (Ratio Richest/Poorest) & 14.60 & 11.69 & 11.40 & 13.19 \\
\hline \multicolumn{5}{|l|}{ Religious affiliation } \\
\hline Muslims & 99.44 & 60.55 & 20.70 & 58.52 \\
\hline Non-Muslims (Including all others) & 112.16 & 65.00 & 31.73 & 64.96 \\
\hline (Ratio Non-Muslims/Muslims) & 1.13 & 1.07 & 1.53 & 1.11 \\
\hline \multicolumn{5}{|l|}{ Social group } \\
\hline ST & 51.20 & 31.40 & 24.86 & 31.00 \\
\hline SC & 64.54 & 60.94 & 27.67 & 55.67 \\
\hline $\mathrm{OBC}$ & 128.26 & 64.60 & 34.40 & 66.00 \\
\hline Others & 132.28 & 73.57 & 29.02 & 77.65 \\
\hline (Ratio Others/ST) & 2.58 & 2.34 & 1.17 & 2.50 \\
\hline
\end{tabular}

Source: Compiled from NSS CES Report (2009-10); computed by author using the unit level data records of CES 2009-10

\section{Discussion}

Equity in healthcare is one of the important and most desired goals to be achieved for any society. Inequalities in healthcare are measured on the basis of health outcome, utilization pattern and level of OOPE, between the Non-poor/Poor, Urban/Rural, Advantaged/ Disadvantaged and other socio-economic groups of the population. Healthcare financing system should focus on achieving vertical equity (households of unequal ability should be treated unequally), horizontal equity (households of the same ability should be treated equally) and progressivity in healthcare expenditure [55-57]. This paper focuses on the equity and regional perspective of healthcare expenditure among Indian states to uncover the linkages and the burden in the form of OOPE. Results indicate that burden of OOPE is not proportional among different subgroups of the population.

People residing in the urban areas, having higher economic status, belonging to non-Muslim and nonST groups were spending significantly higher on healthcare than their counterparts. Literature also

Table 3 Factors associated with OOPE among the households in Indian states $(n=100855)$

\begin{tabular}{lllll}
\hline & \multicolumn{3}{l}{ Categories of states } & \\
\cline { 2 - 5 } & Category A & Category B & Category C & All states \\
\hline Explanatory variables & $\beta(95 \% \mathrm{Cl})$ & $\beta(95 \% \mathrm{Cl})$ & $\beta(95 \% \mathrm{Cl})$ & $\beta(95 \% \mathrm{Cl})$ \\
Muslims & $-0.040(-0.169,-0.089)$ & $-0.021(-0.071,-0.030)$ & $-0.220(-0.289,-0.152)^{* * *}$ & $-0.101(-0.155,-0.047)^{* * *}$ \\
Scheduled Tribe (STs) & $-0.297(-0.467,-0.127)^{* * *}$ & $-0.386(-0.452,-0.319)^{* * *}$ & $-0.281(-0.341,-0.221)^{* * *}$ & $-0.634(-0.687,-0.581)^{* * *}$ \\
Rural & $-0.024(-0.064,-0.112)$ & $-0.001(-0.040,-0.040)$ & $-0.158(-0.226,-0.090)^{* * *}$ & $-0.102(-0.139,-0.065)^{* * *}$ \\
Lowest wealth Quintile & $-1.501(-1.592,-1.410)^{* * *}$ & $-1.419(-1.455,-1.382)^{* * *}$ & $-1.139(-1.195,-1.083)^{* * *}$ & $-1.273(-1.321,-1.225)^{* * *}$ \\
\hline
\end{tabular}

Source: compiled from NSS CES Report (2009-10); computed by author using the unit level data records of CES 2009-10

*** Significant at $1 \%$ level 
indicates that households that belong to the lower socio-economic status (Rural, STs, Muslims and lowest wealth quintile) were constantly experiencing poor health outcomes. This may be due to the fact that these people have minimum access to healthcare facilities or they were not in a position to pay for the use of healthcare services [30, 58, 59].

There is also evidence of regional disparity in terms of healthcare spending among Indian states. It is evident from the results that in Category $A$ states (Kerala, Punjab, Maharashtra, Goa and Chandigarh), the average monthly expenditure on healthcare was highest followed by Category $B$ and $C$. Findings from available literature also supports the fact that Category $A$ states are more affluent with higher per capita income as compared to the other categories of states $(B$ and $C)$. Category $C$ states constitute a higher share of tribal population as compared to the other two categories of states. Due to geographical isolation and inaccessibility, these states are more deprived in terms of availability of healthcare facilities [25, 48, 49].

As in previous studies in the Indian context, our study also indicates progressivity in healthcare financing among Indian states. The incidence of OOPE was higher among Category $A$ states such as, Kerala, Punjab, Maharashtra, Goa, and Chandigarh. However, Category $A$ states face higher burdens of Non-communicable diseases (NCDs), causing them to spend more on healthcare, and resulting into a higher level of OOPE than their counterparts [60-63].

There were noticeable differences in healthcare spending on the basis of economic status (richest/poorest) and social group affiliation (others /STs) among Category $A$ states. In Category $B$ states, inequalities are moderate among the above mentioned socio-economic groups. All these states (Karnataka, Andhra Pradesh, Tamil Nadu, Andaman and Nicobar, Lakshadweep, J\&K, Delhi, Uttarakhand, Haryana, Himachal Pradesh, Rajasthan, Uttar Pradesh, Madhya Pradesh, Gujarat, Tripura and West Bengal) are middle-income states [11, 63, 64].

Economic status and social group affiliation were important determinants of healthcare spending among Category $A$ and $B$ states $[35,55,64]$. Among Category $C$ states (Dadra Nagar Haveli, Daman \& Diu, Sikkim, Nagaland, Assam, Manipur, Meghalaya, Mizoram, Arunachal Pradesh, Bihar, Jharkhand, Chhattisgarh and Orissa) the gap between the rich and the poor, and the disadvantaged social groups and others, is comparatively lower than it was in other categories of states [25]. In the Indian context, income, class, caste and wealth quintile are considered the most powerful stratification variables in assessing socioeconomic inequalities [65].
Multivariate GLRM analysis shows that in Category $A$ and $B$ states, the role of religious affiliation and caste system is comparatively less important, while economic status is considered an important determinant of OOPE. Opposite trends have been observed in Category $\mathrm{C}$ states where the role of caste system continues to be a predominating factor and significantly influences the spending pattern on health. This study brings into focus that even in the $21^{\text {st }}$ century, with all medical advancements and institutional reforms, social institutions still have a significant influence on the healthcare seeking behaviour and spending patterns of households [66, 67]. In the Indian context, religion and caste significantly influence spending pattern among households. Results indicate significant variations in household expenditure on the basis of caste, especially among the STs [33, 34].

Similar observations have been recorded for Category $B$ states where again economic status and social group affiliation are very important contributing factors of OOPE. Here also class concept (Economic status) is more dominant than caste but place of residence does not play an important role [27, 68]. In Category $C$ states, religious affiliation and economic status both are considered equally important determinants of spending on health. Also, social group and place of residence are important determinants of OOPE among Category $C$ states.

In line with the Anderson model, our study also highlights the importance of predisposing, enabling and need factors. As per the categorization of states, the role of these factors in determining the level of OOPE varies significantly in the Indian context. Among Category $A$ states, enabling factors play a more dominant role than predisposing and need variables. A similar pattern was also observed among Category $B$ states. In Category $C$ states, predisposition to use the services such as, caste and residence, still play a major role in the determination of the level of OOPE on healthcare than other factors such as, enabling and need factors [69].

There is also evidence of the geographical concentration of the states on the basis of socio-economic inequalities and OOPE. Especially, Category $C$ states are geographically concentrated more either on the north-eastern or southern eastern side of the country. All these states, which fall in Category $\mathrm{C}$ on the basis of OOPE, are backward states in terms of per capita income as well [70-72]. While examining healthcare spending pattern and level of OOPE as per geographic concentration, it is not easy to state whether these variations are due to geographical factors or not. These variations may be due to differences in 
health-seeking behaviour among the population, and to some extent, the accessibility and availability of services. Instead, socioeconomic factors affect the need for health care and are more accountable for the variations in the level of OOPE [73].

\section{Conclusion}

In this study, we have assessed the level of OOPE, and the socio-economic and regional variations, among all Indian states and UTs. In a developing country like India, where majority of the population spends on healthcare services from their own pockets, higher government spending on health is essential. This study brings into focus healthcare inequalities in India that are based on caste and social groups. The pattern of healthcare expenditure shows large variations in access to quality healthcare by the diverse socio-religious groups in the country. Special focus must be given to financing the health care needs of the disadvantaged sections of the population, as health expenses can push these households into greater risk of poverty through mobilizing funds to cater their healthcare needs. However, designing a financial protection mechanism requires a deeper understanding of both the absolute and relative amounts of the financial burden of OOPE on the households.

There is evidence of regional disparities in terms of the level of OOPE among Indian states. Developed states are spending more on healthcare and backward states are spending less. There is a need to look into why these backward states lag behind their counterparts. Our study brings into focus the issue of inter-state differentials in OOPE causing geographic variation and concentration in healthcare spending. It has been observed that the spending on healthcare was comparatively lower among all the backward or isolated states. Overall social security measures should be enhanced, but at the same time, more priority should be assigned to these disadvantaged states to reduce the burden of OOPE, looking at the regional differences. However, geographical differences cannot explain the OOPE differentials properly and more research is needed to understand why such variation occurs and what efforts are required to address these issues.

Any resulting policy changes should reflect the needs of the backward states and local communities. It was observed that there was an association between the prevalence of socio-economic inequalities and average monthly OOPE. Policy interventions are required from both centre and the states to increase budget allocation for health spending and for reducing the level of OOPE. We hope the findings of our study will be useful for policy makers, researchers and other stakeholders to formulate appropriate strategies for removing regional imbalances in terms of health spending among Indian states.

\section{Limitations of the study}

This study tries to analyse only the absolute burden of healthcare spending by taking into consideration various socio-economic covariates. A limited number of indicators have been taken into consideration due to data limitation, as the source data does not provide information on other important covariates. If other variables are also taken into consideration then results may vary.

\section{Endnotes}

${ }^{1}$ OOPE are non-reimbursable fees which a patient or family is responsible for paying directly to health practitioners or suppliers, without intervention of a third party.

${ }^{2}$ Informal sector economic activities include all forms of non-standard atypical, alternative, irregular and precarious forms of work, and includes all persons in employment who, by law or in practice, are not subject to national labour legislation, income taxation, social protection or entitlement to employment benefits (International Labour Organization (ILO), 2012).

${ }^{3}$ Inpatient expenditure comprises of health care services delivered to patients who are formally admitted to hospitals, ambulatory premises or self-standing centers.

${ }^{4}$ Outpatient expenditure includes expenses on physician's private office, hospital outpatient center or ambulatory-care center. Patient does not stay overnight.

${ }^{5}$ The Scheduled Castes (SCs), Scheduled Tribes (STs) and Other Backward Class (OBC) indicate constitutional classification of various groups of historically disadvantaged indigenous people in India. Various provisions are made by the Constitution of India, to provide reservation, protection and safeguards, in public employment in respect of the persons belonging to the SCs/STs and OBCs.

${ }^{6}$ The Scheduled Castes are sometimes referred to as lower caste or Dalits, and are officially regarded as the socially disadvantaged group of population.

${ }^{7}$ Scheduled Tribes is used as an official term for Adivasi or indigenous people, mainly residing in the hilly, forest or other inaccessible areas. In the Indian context, these people are mainly the indigenous people who are officially regarded as socially disadvantaged.

${ }^{8}$ Other Backward Class (OBC) is a collective term used by the Constitution of India to categorize castes which are socially and educationally disadvantaged. 


\section{Appendix}

Table 4 Average monthly per capita OOPE (In Rs.), average OOPE Share (\%) to total and non-food expenditure by rural and urban areas of major Indian states, CES 2009-10

\begin{tabular}{|c|c|c|c|}
\hline \multirow[t]{2}{*}{ States } & \multirow{2}{*}{$\begin{array}{l}\text { Rural } \\
\text { Average per capita OOPE (In Rs.) }\end{array}$} & \multirow{2}{*}{$\begin{array}{l}\text { Urban } \\
\text { Average per capita OOPE (In Rs.) }\end{array}$} & \multirow{2}{*}{$\begin{array}{l}\text { All India } \\
\text { Average per capita OOPE (In Rs.) }\end{array}$} \\
\hline & & & \\
\hline$J \& K$ & 66 & 50 & 62 \\
\hline Himachal Pradesh & 89 & 115 & 92 \\
\hline Punjab & 143 & 123 & 136 \\
\hline Chandigarh & 25 & 129 & 113 \\
\hline Uttaranchal & 68 & 98 & 76 \\
\hline Haryana & 83 & 79 & 82 \\
\hline Delhi & 18 & 55 & 53 \\
\hline Rajasthan & 48 & 73 & 54 \\
\hline Uttar Pradesh & 63 & 74 & 66 \\
\hline Bihar & 26 & 53 & 29 \\
\hline Sikkim & 11 & 17 & 13 \\
\hline Arunachala Pradesh & 41 & 66 & 47 \\
\hline Nagaland & 13 & 14 & 14 \\
\hline Manipur & 18 & 25 & 21 \\
\hline Mizoram & 18 & 33 & 25 \\
\hline Tripura & 56 & 121 & 67 \\
\hline Meghalaya & 19 & 34 & 22 \\
\hline Assam & 18 & 37 & 20 \\
\hline West Bengal & 47 & 136 & 69 \\
\hline Jharkhand & 27 & 42 & 31 \\
\hline Orissa & 34 & 69 & 39 \\
\hline Chhattisgarh & 31 & 62 & 36 \\
\hline Madhya Pradesh & 44 & 84 & 54 \\
\hline Gujarat & 48 & 120 & 75 \\
\hline$D \& D$ & 15 & 28 & 21 \\
\hline Dadra \& Nagra Haveli & 2 & 11 & 4 \\
\hline Maharashtra & 78 & 136 & 102 \\
\hline Andhra Pradesh & 63 & 99 & 73 \\
\hline Karnataka & 38 & 78 & 52 \\
\hline Goa & 109 & 114 & 110 \\
\hline Lakshadweep & 73 & 89 & 82 \\
\hline Kerala & 179 & 198 & 184 \\
\hline Tamil Nadu & 71 & 105 & 86 \\
\hline Pondicherry & 96 & 126 & 116 \\
\hline Andaman and Nicobar & 34 & 109 & 63 \\
\hline India & 57 & 99 & 68 \\
\hline
\end{tabular}

Source: compiled from NSS CES Report (2009-10); computed by author using the unit level data records of CES 2009-10 
Table 5 Average monthly per capita medical institutional (In Rs.), non-institutional and total health expenditure by rural and urban areas of major Indian states, CES 2009-10

\begin{tabular}{|c|c|c|c|c|c|c|c|c|c|}
\hline \multirow[t]{2}{*}{ States } & \multicolumn{3}{|l|}{ Rural } & \multicolumn{3}{|l|}{ Urban } & \multicolumn{3}{|l|}{ All India } \\
\hline & $\begin{array}{l}\text { Per capita } \\
\text { institutional } \\
\text { expenditure }\end{array}$ & $\begin{array}{l}\text { Per capita } \\
\text { non- } \\
\text { institutional } \\
\text { expenditure }\end{array}$ & $\begin{array}{l}\text { Per capita } \\
\text { total health } \\
\text { expenditure }\end{array}$ & $\begin{array}{l}\text { Per capita } \\
\text { institutional } \\
\text { expenditure }\end{array}$ & $\begin{array}{l}\text { Per capita } \\
\text { non- } \\
\text { institutional } \\
\text { expenditure }\end{array}$ & $\begin{array}{l}\text { Per capita } \\
\text { total health } \\
\text { expenditure }\end{array}$ & $\begin{array}{l}\text { Per capita } \\
\text { institutional } \\
\text { expenditure }\end{array}$ & $\begin{array}{l}\text { Per capita } \\
\text { non- } \\
\text { institutional } \\
\text { expenditure }\end{array}$ & $\begin{array}{l}\text { Per capita } \\
\text { total health } \\
\text { expenditure }\end{array}$ \\
\hline$J \& K$ & 29 & 37 & 66 & 9 & 41 & 50 & 24 & 38 & 62 \\
\hline $\begin{array}{l}\text { Himachal } \\
\text { Pradesh }\end{array}$ & 32 & 58 & 90 & 41 & 74 & 115 & 33 & 59 & 92 \\
\hline Punjab & 59 & 85 & 144 & 35 & 87 & 123 & 51 & 86 & 136 \\
\hline Chandigarh & 0 & 26 & 26 & 50 & 79 & 129 & 43 & 71 & 113 \\
\hline Uttaranchal & 19 & 49 & 68 & 37 & 61 & 98 & 24 & 52 & 76 \\
\hline Haryana & 33 & 50 & 83 & 27 & 52 & 79 & 31 & 50 & 82 \\
\hline Delhi & 0 & 19 & 19 & 25 & 30 & 55 & 23 & 29 & 53 \\
\hline Rajasthan & 15 & 33 & 48 & 20 & 53 & 73 & 16 & 38 & 54 \\
\hline Uttar Pradesh & 18 & 46 & 64 & 20 & 55 & 74 & 18 & 48 & 66 \\
\hline Bihar & 3 & 23 & 26 & 9 & 44 & 53 & 4 & 25 & 29 \\
\hline Sikkim & 2 & 10 & 12 & 1 & 16 & 17 & 1 & 11 & 13 \\
\hline $\begin{array}{l}\text { Arunachala } \\
\text { Pradesh }\end{array}$ & 16 & 26 & 42 & 27 & 38 & 66 & 18 & 28 & 47 \\
\hline Nagaland & 2 & 11 & 13 & 2 & 12 & 14 & 2 & 11 & 14 \\
\hline Manipur & 4 & 15 & 19 & 7 & 18 & 25 & 5 & 15 & 21 \\
\hline Mizoram & 2 & 16 & 18 & 6 & 28 & 33 & 4 & 21 & 25 \\
\hline Tripura & 14 & 42 & 57 & 24 & 97 & 121 & 16 & 51 & 67 \\
\hline Meghalaya & 5 & 15 & 20 & 7 & 27 & 34 & 5 & 17 & 22 \\
\hline Assam & 4 & 15 & 19 & 8 & 29 & 37 & 4 & 16 & 20 \\
\hline West Bengal & 12 & 36 & 48 & 45 & 90 & 136 & 20 & 49 & 69 \\
\hline Jharkhand & 7 & 21 & 28 & 8 & 35 & 42 & 7 & 24 & 31 \\
\hline Orissa & 6 & 28 & 34 & 22 & 47 & 69 & 8 & 31 & 39 \\
\hline Chhattisgarh & 5 & 25 & 31 & 25 & 37 & 62 & 9 & 27 & 36 \\
\hline $\begin{array}{l}\text { Madhya } \\
\text { Pradesh }\end{array}$ & 9 & 35 & 44 & 22 & 61 & 84 & 12 & 41 & 54 \\
\hline Gujarat & 28 & 20 & 48 & 65 & 55 & 120 & 42 & 33 & 75 \\
\hline$D \& D$ & 5 & 10 & 15 & 14 & 14 & 28 & 9 & 12 & 21 \\
\hline $\begin{array}{l}\text { Dadra and } \\
\text { Nagra Haveli }\end{array}$ & 0 & 2 & 2 & 7 & 4 & 11 & 2 & 2 & 4 \\
\hline Maharashtra & 32 & 46 & 78 & 55 & 81 & 136 & 42 & 60 & 102 \\
\hline $\begin{array}{l}\text { Andhra } \\
\text { Pradesh }\end{array}$ & 18 & 45 & 63 & 28 & 71 & 99 & 21 & 52 & 73 \\
\hline Karnataka & 10 & 28 & 38 & 28 & 50 & 78 & 16 & 36 & 52 \\
\hline Goa & 23 & 86 & 109 & 39 & 75 & 114 & 27 & 83 & 110 \\
\hline Lakshadweep & 57 & 17 & 73 & 64 & 25 & 89 & 60 & 21 & 82 \\
\hline Kerala & 70 & 109 & 179 & 78 & 120 & 198 & 72 & 112 & 184 \\
\hline Tamil Nadu & 20 & 50 & 71 & 28 & 76 & 105 & 24 & 62 & 86 \\
\hline Pondicherry & 19 & 77 & 96 & 23 & 103 & 126 & 22 & 94 & 116 \\
\hline $\begin{array}{l}\text { Andaman } \\
\text { and Nicobar }\end{array}$ & 25 & 9 & 34 & 81 & 28 & 109 & 46 & 16 & 63 \\
\hline India & 18 & 39 & 57 & 34 & 65 & 99 & 22 & 46 & 68 \\
\hline
\end{tabular}

Source: compiled from NSS CES Report (2009-10); computed by author using the unit level data records of CES 2009-10 


\section{Abbreviations}

CES: Consumer Expenditure Survey; GLRM: Generalized Linear Regression Model; Gol: Government of India; ILO: International Labour Organization; J\&K: Jammu and Kashmir; LMICs: Low- and Middle-Income Countries; MoSPI: Ministry of Statistics and Programme Implementation; NSSO: National Sample Survey Organization; NCDs: Non-communicable diseases;

OLS: Ordinary Least Square; OBC: Other Backward Caste; OOPE: Out of Pocket Expenditure; SC: Scheduled Caste; ST: Scheduled Tribe; UTS: Union Territories; UHC: Universal Health Coverage; WHO: World Health Organization

\section{Acknowledgements}

The authors are grateful to the Department of Humanities and Social Sciences, National Institute of Technology (NIT), Rourkela for their support and encouragement, which has helped in improving this paper. The authors also thank the journal editor and reviewers for their insightful comments which greatly helped improve this paper.

\section{Funding}

We received no funding support to undertake this study.

\section{Availability of data and materials}

This paper uses data from the unit level information from $66^{\text {th }}$ quinquennial CES round of the NSSO, conducted under the aegis of the Ministry of Statistics and Programme Implementation, Government of India. For more details see the report "Level and Pattern of Consumer Expenditure" 2009-10, by NSSO, Ministry of Statistics and Programme Implementation, Government of India, New Delhi: http://164.100.34.62/index.php/catalog/20/related_materials.

\section{Authors' contributions}

Design of the study: RD, JP. Wrote the Paper: RD. Analysed the data: RD with the help of JP. Finalising the article: RD, JP. All authors read and approved the final manuscript.

\section{Authors' information}

RD is Senior Research Fellow (SRF), and JP is assistant professor in Health Economics with the Department of Humanities and Social Sciences, National Institute of Technology (NIT), Rourkela, Odisha. Their research interests include healthcare financing, specifically health equity and inequality perspective in health economics.

\section{Competing interests}

The authors declare that they have no competing interests.

\section{Consent for publication}

We have bought this data from NSSO to use in our research. This data is also available in public domain for research purpose.

\section{Ethics approval and consent to participate}

N.A. As this study uses secondary data so no consent to participate is required by the authors.

\section{Author details}

${ }^{1}$ Research Scholar Department of Humanities and Social Sciences, National Institute of Technology, Rourkela, Odisha 769 008, India. ${ }^{2}$ Department of Humanities and Social Sciences, National Institute of Technology, Rourkela, Odisha 769 008, India.

Received: 17 March 2016 Accepted: 3 January 2017 Published online: 14 January 2017

\section{References}

1. Walt G, Gilson L. Reforming the health sector in developing countries: the central role of policy analysis. Health Policy Planning. 1994;9(4):353-70.

2. Baum F. Health for All Now! Reviving the spirit of Alma Ata in the twentyfirst century: An Introduction to the Alma Ata Declaration. Soc Med. 2007; 2(1):34-41.

3. Ranson MK, Chopra M, Atkins S, Dal Poz MR, Bennett S. Priorities for research into human resources for health in low-and middle-income countries. Bull World Health Organ. 2010;88(6):435-43.
4. Mclntyre D, Thiede M, Dahlgren G, Whitehead M. What are the economic consequences for households of illness and of paying for health care in low-and middle-income country contexts? Soc Sci Med. 2006;62(4):858-65.

5. Carrin G, Waelkens MP, Criel B. Community-based health insurance in developing countries: a study of its contribution to the performance of health financing systems. Trop Med Int Health. 2005;10(8):799-811.

6. O'Donnell OA, Wagstaff A. Analyzing health equity using household survey data: a guide to techniques and their implementation. World Bank Publications; 2008. http://siteresources.worldbank.org/INTPAH/Resources/ Publications/459843-1195594469249/HealthEquityFINAL.pdf.

7. Abeysinghe T, Lim J. Singapore's healthcare financing: Some challenges, The Singapore Economic Policy Conference. 2009.

8. De Graeve PD, Schokkaert E, Cantillon B. Equity in the Finance of Healthcare : Summary,1-10. 2003. www.belspo.be/belspo/organisation/publ/pub_ostc/ .../rSO01005_e. Accessed on 21st Nov 2014.

9. Leive A, Xu K. Coping with out-of-pocket health payments: empirical evidence from 15 African countries. Bull World Health Organ. 2008;86(11):849-856C.

10. Akazili J, Garshong B, Aikins M, Gyapong J, Mclntyre D. Progressivity of health care financing and incidence of service benefits in Ghana. Health Policy Planning. 2012;27 suppl 1:113-22.

11. O'donnell O, Van Doorslaer E, Rannan-Eliya RP, Somanathan A, Adhikari SR, Akkazieva $B, \ldots$ Huq MN. Who pays for health care in Asia? J Health Econ. 2008;27(2):460-475.

12. Joglekar R. Can insurance reduce catastrophic out-of-pocket health expenditure? Indira Gandhi Institute of Development Research, Mumbai. 2012 (September 2008). http://www.igidr.ac.in/pdf/publication/WP-2008-016.pdf. Accessed on 21st Nov 2014.

13. Helligso JAR. A microeconomic model of healthcare systems: from theoretical to practical. Orlando: Doctoral dissertation, University of Central Florida; 2007.

14. Gunther I, Harttgen K. Estimating Households Vulnerability to Idiosyncratic and Covariate Shocks: A Novel Method Applied in Madagascar. World Development. 2009;37:1222-34

15. Amakom U, Ezenekwe U. Implications of households catastrophic out of pocket (OOP) healthcare spending in Nigeria. J Res Econ Int Finance (JREIF). 2012;1(5):136-40.

16. WHO. Health systems financing: The path to iniversal coverage, The World Health Report. 2010. p. 1-128. http://whqlibdoc.who.int/whr/2010/ 9789241564021_eng.pdf.

17. Mtei G, Makawia S, Ally M, Kuwawenaruwa A, Meheus F, Borghi J. Who pays and who benefits from health care? An assessment of equity in health care financing and benefit distribution in Tanzania. Health Policy Plan. 2012;27(1):23-34.

18. Xu K, Evans DB, Kawabata K, Zeramdini R, Klavus J, Murray CJ. Household catastrophic health expenditure: a multicounty analysis. Lancet. 2003; 362(9378):111-7.

19. Xu K, Klavus J, Kawabata K, Evans DB, Hanvoravongchai P, Ortiz JP, Murray CJL. Household Health System Contributions and Capacity to Pay : Definitional, Empirical, and Technical Challenges, Health Systems Performance Assessment: Debates, Methods and Empiricism. 2003. p. 533-42.

20. Amendah DD, Buigut S, Mohamed S. Coping strategies among urban poor: evidence from Nairobi, Kenya. PloS One. 2014;9(1):e83428.

21. International Labour Office. World Social Protection Report (2014/15) Building economic recovery, inclusive development and social justice. Geneva: ILO; 2014.

22. Xu K. Distribution of health payments and Catastrophic expenditures Methodology, Discussion Paper. World Health Organization (WHO); 2005. http://www.who.int/health_financing/documents/dp_e_05_2distribution_ of_health_payments.pdf.

23. Or Z, Jusot F, Yilmaz E. Impact of health care system on socioeconomic inequalities in doctor use. Working paper, IRDES; 2008. http://www.irdes.fr/ EspaceAnglais/Publications/WorkingPapers/DT17ImpactHealthCareSyst Socioeconomiclnequalities.pdf.

24. Xie X, Wu Q, Hao Y, Yin H, Fu W, Ning N, Liu G. Identifying Determinants of Socioeconomic Inequality in Health Service Utilization among Patients with Chronic Non-Communicable Diseases in China. PloS One. 2014;9(6):e100231.

25. Government of India (Gol). Data-book Compiled for use of Planning Commission. Directorate of Economics Statistics of respective State Governments, and for AllIndia. New Delhi: Central Statistical Organisation (CSO); 2014.

26. Ministry of Health and Family Welfare (MOHFW), Government of India. National Health Accounts (NHA) India 2004-05. 2009.

27. Modugu HR, Kumar M, Kumar a, Millett C. State and socio-demographic group variation in out-of-pocket expenditure, borrowings and Janani Suraksha Yojana (JSY) programme use for birth deliveries in India. BMC 
Public Health. 2012;12:1048. http://bmcpublichealth.biomedcentral.com/ articles/10.1186/1471-2458-12-1048.

28. Selvaraj S, Karan AK. Health Deepening Insecurity in India : Evidence from National Sample Surveys since 1980s. Econ Polit Wkly.

2013;44(40):55-60

29. Gopalan SS, Durairaj V. Addressing maternal healthcare through demand side financial incentives: experience of Janani Suraksha Yojana program in India. BMC Health Services Research. 2012;12(1):319. https://bmchealthservres.biomedcentral. com/articles/10.1186/1472-6963-12-319.

30. Prinja S, Bahuguna P, Pinto AD, Sharma A, Bharaj G, Kumar V, Kumar R. The cost of universal health care in India: a model based estimate. PLoS One. 2012;7(1):e30362.

31. Duggal R. Poverty \& health: criticality of public financing. Indian J Med Res 2007;126(4):309.

32. WHO. Health financing for universal coverage: What is universal coverage? 2013. Retrieved from http://www.who.int/health_financing/universal_ coverage_definition/en.

33. Government of India (Gol). Report of the Committee on Unorganised Sector Statistics. New Delhi: Government of India; 2012.

34. National Sample Survey Organization (NSSO). Informal sector and conditions of employment in India, Ministry of Statistics and Programme Implementation. New Delhi: Government of India; 2012.

35. Mukherjee S, Haddad S, Narayana D. Social class related inequalities in household health expenditure and economic burden: evidence from Kerala, south India. Int J Equity Health. 2011;10(1):1.

36. Chaudhuri A. Socio-economic inequity in health care utilization \& expenditures in richer States in India. Indian J Med Res. 2012;136:368-9.

37. Bonu S, Bhushan I, Rani M, Anderson I. Incidence and correlates of "catastrophic" maternal health care expenditure in India. Health Policy Planning. 2009;24(6):445-56.

38. Garcia-Subirats I, Vargas I, Mogollon-Perez AS, De Paepe P, da Silva MR, Unger JP, Vazquez ML. Inequities in access to health care in different health systems: a study in municipalities of central Colombia and north-eastern Brazil. Int J Equity Health. 2014;13(10):1-15.

39. Mahal A, Fan V. Achieving Universal health Coverage in India: An Assessment of the Policy Challenge. Melbourne: Monash University School of Public Health and Preventive Medicine and Harvard School of Public Health; 2011.

40. Wagstaff A, van Doorslaer E. Overall versus socioeconomic health inequality: a measurement framework and two empirical illustrations. Health Econ. 2004;13(3):297-301. http://doi.org/10.1002/hec.822.

41. Van Doorslaer E, Wagstaff A, Van der Burg H, Christiansen T, De Graeve D, Duchesne I, Winkelhake O. Equity in the delivery of health care in Europe and the US. J Health Econ. 2000;19(5):553-83.

42. Baru R, Acharya A, Acharya S, Kumar AS, Nagaraj K. Inequities in access to health services in India: caste, class and region. Econ Polit Wkly. 2010;45(38):49-58.

43. Barik D, Desai S. Determinants of private healthcare utilization and expenditure patterns in India. http://www.ihds.info/sites/default/files/publications/papers/ barik\%20and\%20desai\%202014\%20health\%20expenditure.pdf. Accessed on 21st Nov 2014

44. Deshpande A. Does caste still define disparity? A look at inequality in Kerala, India. Am Econ Rev. 2000;90(2):322-5.

45. International Institute for Population Sciences (IIPS) and Macro International. National Family Health Survey (NFHS-3), 2005-06: India: Volume I. Mumbai: IIPS, 2007. http://rchiips.org/Nfhs/NFHS-3\%20Data/NOL-1/India_volume_I_ corrected_17oct08.pdf.

46. Roy TK, Kulkarni S, Vaidehi Y. Social inequalities in health and nutrition in selected states. Econ Polit Wkly. 2004;39(7):677-83.

47. Rao MG, Choudhury M. Health care financing reforms in India. The Economics of Public Health Care Reform in Advanced and Emerging Economies, edited by Benedict Clements, David Coady and Sanjeev Gupta, International Monetary Fund. 2012.

48. Prachitha J, Shanmugam KR. Efficiency of raising health outcomes in Indian states, Madras School of Economics working paper (No. 2012-070). 2012

49. Prinja S, Kanavos P, Kumar R. Health care inequalities in north India: Role of public sector in universalizing health care. Indian J Med Res. 2012;136(3):421-31.

50. Meyer BD, Sullivan JX. Viewpoint: Further results on measuring the well-being of the poor using income and consumption. Can J Econ. 2011;44(1):52-87.

51. Ariza-Montoya JF, Hernández-Álvarez ME. Ethnic equity in accessing health services in Bogotá, Colombia, 2007. Revista de Salud Pública. 2008;10:58-71.

52. Manning WG. The logged dependent variable, heteroscedasticity, and the retransformation problem. J Health Econ. 1998;17(3):283-95.
53. Basu A, Manning WG. Issues for the next generation of health care cost analyses. Med Care. 2009;47(7_Supplement_1):S109-14.

54. Gregori D, Petrinco M, Bo S, Desideri A, Merletti F, Pagano E. Regression models for analyzing costs and their determinants in health care: an introductory review. Int J Qual Health Care. 2011;1-11, mzr010. http://dx.doi. org/10.1093/intahc/mzr010.

55. Jahangir E, Irazola V, Rubinstein A. Need, enabling, predisposing, and behavioral determinants of access to preventative care in Argentina: analysis of the national survey of risk factors. PloS One. 2012;7(9):e45053.

56. Sample Registration Survey (SRS.) Bulletin. Registrar General of India. New Delhi: Government of India; 2006.

57. Kilian R, Matschinger $H$, Loffler W, Roick C, Angermeyer MC. A comparison of methods to handle skew distributed cost variables in the analysis of the resource consumption in schizophrenia treatment. J Ment Health Policy Econ. 2002;5(1):21-32.

58. Mills A, Ataguba JE, Akazili J, Borghi J, Garshong B, Makawia S, Mclntyre D. Equity in financing and use of health care in Ghana, South Africa, and Tanzania: implications for paths to universal coverage. Lancet. 2012;380(9837):126-33.

59. Cisse B, Luchini S, Moatti JP. Progressivity and horizontal equity in health care finance and delivery: What about Africa? Health Policy. 2007;80(1):51-68.

60. Popkin BM, Horton S, Kim S, Mahal A, Shuigao J. Trends in diet, nutritional status, and diet-related non-communicable diseases in China and India: the economic costs of the nutrition transition. Nutr Rev. 2001;59(12):379-90.

61. Ghosh S. Catastrophic payments and Impoverishment due to Out-of-Pocket health spending: The effects of recent health sector reforms in India, Asia Health Policy Program Working Paper, (15). 2010.

62. Roy K, Howard DH. Equity in out-of-pocket payments for hospital care: evidence from India. Health Policy. 2007;80(2):297-307.

63. Narang R. Measuring perceived quality of health care services in India. Int J Health Care Qual Assurance. 2010;23(2):171-86.

64. Subramanian SV, Davey Smith G, Subramanyam M. Indigenous health and socioeconomic status in India. PLoS Med. 2006;3(10):e421.

65. Nayar KR. Social exclusion, caste \& health: a review based on the social determinants framework. Indian J Med Res. 2007;126(4):355.

66. Acharya A, Vellakkal S, Taylor F, Masset E, Satija A, Burke M, Ebrahim S. Impact of national health insurance for the poor and the informal sector in low-and middle-income countries, vol. 4. London: EPPI-Centre, Social Science Research Unit, Institute of Education, University of London; 2012.

67. Farahani M, Subramanian SV, Canning D. Effects of state-level public spending on health on the mortality probability in India. Health Econ. 2010; 19(11):1361-76.

68. Balarajan Y, Selvaraj S, Subramanian SV. Health care and equity in India. Lancet. 2011;377(9764):505-15.

69. Prinja S, Aggarwal A, Kumar R. Impact of decentralization and user charges on health systems and health services utilization in North India. School of Public Health. Chandigarh: PGIMER; 2008.

70. Garg CC, Karan AK. Reducing out-of-pocket expenditures to reduce poverty: a disaggregated analysis at rural-urban and state level in India. Health Policy Planning. 2009;24(2):116-28.

71. Ravallion M, Datt G. Why has economic growth been more pro-poor in some states of India than others? J Dev Econ. 2002;68(2):381-400.

72. Berman P, Ahuja R, Bhandari L. The impoverishing effect of healthcare payments in India: new methodology and findings. Econ Polit Wkly. 2010;45(16):65-71.

73. Beteille A. Caste, Class and Power: Changing Patterns of Stratification in a Tanjore Village; The Idea of Natural Inequality and Other Essays; Equality and Universality: Essays in Social and Political Theory. Second edition. Delhi: Oxford University Press; 1996. 